\title{
O ATAQUE AOS DIREITOS INDÍGENAS NO BRASIL ATUAL: A DIMENSÃO IMAGINÁRIA DA TENSÃO ENTRE ASSIMILAÇÃO E ADMISSÃO DA DIFERENÇA INDÍGENA
}

\author{
MÔNICA THEREZA SOARES PECHINCHA ${ }^{1}$
}

$U F G$

\begin{abstract}
RESUMO: A partir de aspectos históricos concernentes ao direito indígena a terras no Brasil desde o período colonial, correlaciono legislação, técnicas de governamentalidade $e$ imaginário de amplo apelo na sociedade e de longa duração, com vistas a lançar luz sobre o atual ataque aos direitos indígenas no país por parte de políticos e interesses econômicos associados. Verifico três dimensões de discurso e as técnicas que articulam: a econômica, a jurídica, ambas apenas inteligíveis sob os marcos próprios de construção de alteridades no estado-nação brasileiro; e a dimensão "mitológica", aqui entendida no sentido estruturalista de imaginário. Nesta última, encontro uma idealização que se desloca entre a aliança possível e a tutela/impotência dos índios. Concluo que a dimensão imaginária acrescenta sentido ao entendimento da tensão permanente e ainda operante entre assimilação $e$ admissão da diferença indígena na nação brasileira hoje.
\end{abstract}

PALAVRAS-CHAVE: ataque aos direitos territoriais indígenas; técnicas de governamentalidade; imaginário; nação plural.

ABSTRACT: By selecting historical aspects related to indigenous land rights in Brazil since the colonial period, I made a correlation between legislation, governmentality techniques and an imaginary of broad appeal and of long term in society, in order to shed light on the current attack on indigenous rights in the country by politicians and associated economic interests. I check three dimensions of discourse and the techniques that they articulate: economic, legal, both only intelligible under the very landmarks of otherness constructions in the Brazilian nation-state; and a "mythical" dimension, understood here in the structuralist sense of imaginary. In the latter, I find an idealization that moves between the alliance possible and tutelage/impotence of the Indians. I conclude that the imaginary dimension adds meaning to the understanding of the permanent tension still operating in the Brazilian nation today between assimilation and admission of indigenous difference.

KEYWORDS: attack on indigenous rights; governmentality techniques; imaginary; plural nation.

\footnotetext{
${ }^{1}$ Mestre e doutora em Antropologia pela Universidade de Brasília (UnB). Professora da Faculdade de Ciências Sociais, do Programa de Pós-Graduação em Antropologia Social e do Curso de Educação Intercultural do Núcleo Takinahakỹ de Formação Superior Indígena da Universidade Federal de Goiás (UFG). E-mail: mpechincha@ hotmail.com .
} 
A história da legislação indígena e do indigenismo oficial nos períodos colonial, do Império e da República, que foi deslindada analiticamente principalmente para demarcar as especificidades de cada época (PERRONE-MOISÉS, 1992; CARNEIRO DA CUNHA, 1992a, 1992b; LIMA, 1992 e 1995, entre outros), mostra uma curiosa continuidade de disposição. Esta revela-se na observação que fizeram os estudiosos da intrigante vacilação nos mandamentos que asseguram direitos aos índios, sobretudo o direito à posse ou propriedade de terras e, principalmente, está expressa nas manobras para burlar a sua aplicação. A despeito de todas as atrocidades cometidas contra os índios no decorrer da história do Brasil, no período da colônia, ao contrário do que se poderia pensar, os índios foram reconhecidos como livres (PERRONE-MOISÉS, 2000) e como donos de suas terras. Tais princípios não foram totalmente apagados no Império, mesmo que neste período apareçam já com as inflexões e limites consentidos pela grande influência do evolucionismo social europeu oitocentista no Brasil. Apesar do reconhecimento do direito às terras, no Império, quando a legislação indigenista se fez mais exígua se comparada à do período colonial, dá-se ainda a continuidade às ações coloniais de descimento, controle e confinamento territorial. Nas palavras de Carneiro da Cunha, no século XIX, crescentemente interessado na questão de terras, "os índios ocupam uma posição singular, já que têm de ser legalmente, senão legitimamente, despossuídos de uma terra que sempre lhes foi, por direito, reconhecida" (1992a, p. 141). Já o indigenismo do século XX pré-Constituição de 1988, inspirado no evolucionismo positivista nacionalista, tem seu mote na esperança na assimilação "harmoniosa", na tutela e na recompensa do trabalho indígena, no uso da renda indígena (renda do patrimônio indígena) e na liberação de terras para a colonização do interior do país. Ainda assim, o direito à propriedade ou da posse dos índios sobre as terras que ocupam está, sob diferentes ordenamentos jurídicos, nos três períodos.

A continuidade de disposição da política indigenista a que me refiro pode ser qualificada como Perrone-Moisés (1992) o fez em relação à política da coroa portuguesa, que teria sido "contraditória, oscilante, hipócrita", como assinala a autora, subscrevendo uma 
qualificação unânime de outros analistas. Perrone-Moisés (1992) chama a atenção para o descuido de observação comum em relação aos princípios de uma tradição jurídica expressa na legislação indigenista portuguesa no Brasil, que não seria, como contesta, meramente o reflexo de pressões políticas e econômicas, mas a própria justificava da presença europeia na América, dada pela conversão religiosa e cultural. Assim o sendo, a legislação colonial ora declara a liberdade dos índios, ora abole casos legais de cativeiro, ora os restaura. $\mathrm{Na}$ verdade, segundo a autora, se trataria de duas linhas de política indigenista, dirigidas uma aos índios aliados e aldeados, outra aos inimigos.

\begin{abstract}
O tratamento "bondoso e pacífico" é recomendado para todos os índios aldeados e aliados. O tratamento preferencial é recomendado para trazer os índios à conversão e aldeamento, e para garantir as alianças. As razões apontadas para justificar os bons tratos são variadas, indo desde os mais básicos princípios de direito até a uma alegada inconstância dos índios, que pode leva-los a retornar aos matos e à "gentilidade", se forem maltratados.... A recomendação de tratamento bondoso e pacífico dos índios aldeados baseia-se, até o fim do século VIII, em razões de ordem religiosa: a conversão, objetivo primeiro da colonização, só poderia ser conseguida com brandura, e só seria efetiva se os cristãos dessem aos índios o bom exemplo de seu próprio comportamento (PERRONE-MOISÉS, 1992, p. 122).
\end{abstract}

A partir do século XIX os interesses de conversão se secularizam, mesmo que parcialmente, pois a ação missionária nunca foi dispensável aos intentos de incorporação dos índios à nação brasileira - mas não esses intentos. O que interessa para os fins da análise que procedo é que em toda a história do indigenismo de estado no Brasil pairou a vacilação, dado o reconhecimento do direito à terra, entre índios aliados e índios inimigos, entre aqueles a que se podia forçar a rendição aos interesses coloniais e nacionais e os que não se poderia, com pretenso sossego no período republicano no vislumbre das etapas de integração e liberação sequencial e total das terras. Se os princípios jurídicos pretendem traduzir a mais elevada e insigne ética de um tempo, argumento neste texto que o princípio do não integracionismo, que é o de nossa época, está na raiz da "contradição, oscilação e hipocrisia" que 
se percebem atualmente nas manobras legislativas com as que se pretende atacar os direitos indígenas. Meu argumento vai na direção de que esta seria a razão da dificuldade da nação brasileira em assumir-se como multiétnica, já assinalada, ademais, por quem a tem analisado recentemente (ver LIMA, 2012; CAVALCANTI-SCHIEL, 2009).

Menos que uma reconstituição exaustiva dessa história, centralizo os deslizamentos ou os transbordamentos simbólicos inevitáveis (e por que o são?), entre a posição jurídica dos índios e a imagem que se tem do índio de forma geral na sociedade brasileira, que podem ser apreendidas nos discursos de opositores aos direitos assegurados aos índios e na sua repercussão ampliada. Para fazê-lo, interrogo o lugar que o índio ocupa na imaginação da nação, que caracterizo a partir do lema subjacente da vacilação acima aludida, que é de longa duração: o que ao mesmo tempo permite e nega, se dá e se tira. Em nossa época, a suspensão do princípio assimilacionista dá passagem ao aflorar de um ódio sôfrego contra os índios, uma vez que retira o que restava de esperança na moralidade jurídica que desde sempre operou o reconhecimento das terras - ou seja, desde que este reconhecimento pudesse, por fim, ser interrompido na assimilação/catequização/civilização/integração.

\section{O "estado-nação ainda colonial"}

No entendimento jurídico, a Constituição de 1988 reforçou extraordinariamente o posicionamento dos índios e suas comunidades em termos da legislação brasileira (DALLARI, 1991). Desta feita, esta passou a se qualificar como avançada no que tange ao reconhecimento de direitos indígenas. Hoje, encontramo-nos em um momento, todavia, em que todo tipo de desrespeito, violência física e implacáveis e insistentes ameaças a estes direitos rondam perigosamente os avanços firmados na letra da lei - ademais como na história. São projetos de lei, de propostas de emenda à Constituição, de ações e interpretações judiciais, de paralização de processos administrativos de demarcação de terras. É de conhecimento geral, pois que alçou a conformação de um debate público, a investida agressiva de setores econômicos e políticos 
vinculados aos interesses do agronegócio e mineral nos anos recentes, que replicam os ímpetos capitalistas transnacionais no continente - e que têm em vista o espólio de terras ocupadas coletivamente por indígenas.

Como há muito se ouve nas reivindicações dos movimentos indígenas, já seria uma grande conquista se a legislação indigenista fosse aplicada. Menos que interpretar a efetividade da lei por si só, ou fazer mais um arrazoado de que o desrespeito à lei no Brasil é estrutural2, a pergunta que lanço dirige-se a um patamar de moralidade, à assistência impassível, à normalização, no Brasil de hoje, da ideia de que as vidas dos indígenas não importam. Faço esta pergunta concordando com a ressalva que a antropóloga Elizabeth Povinelli (2006) lança à teoria da vida nua de Agamben, de que esta se apresenta mesmo nos momentos mais cotidianos, em formas de sofrimento ordinário e em resistência crônicas frente aos desafios constantes à sustentação de mundos alternativos, como os indígenas. Para além da razão pública que reclama para si uma dignidade fundada em princípios de direito, há uma disputa - que se justifica como racional ou sob uma "razão prática" - que reedita a tensão e a crise, que, por sua vez, permanecem e modulam o grau do tolerável, daquilo que é considerado um ato ou uma postura violenta ou não violenta frente a esses outros e como essa separação é feita. Se a explicação para esta modulação pode ser encontrada nas manobras do reconhecimento liberal frente a indígenas ao redor do mundo, ela tem que ser buscada também no cipoal inconsciente, nos elementos da fantasia e da fantasmagoria da imaginação nacional brasileira.

Ainda que a disjunção entre lei escrita e práticas indigenistas do estado não tenha se superado mesmo em momentos mais acalentados de esperança democrática pós-1988, estamos em tempos em que a exceção quer se colocar por sobre os direitos reconhecidos aos indígenas, como se, para setores da sociedade que têm ampla influência nos processos de decisão governamentais, jurídicas e judiciais e que contam com considerável suporte midiático e comunicacional, o limite

\footnotetext{
${ }^{2}$ Em análise dos mesmos fatos, Capiberibe e Bonilla observam que: "A despeito da ideia generalizada de que no Brasil as leis 'não pegam', há cada vez mais uma percepção da legislação como instrumento estratégico e batalha no congresso" (2015, p. 297).
} 
da lei tivesse se estendido demais. Os interesses que defendem interesses da propriedade privada, justificados por metas de desenvolvimento econômico - são óbvios e prescindem de grande esforço analítico de interpretação. Todavia, enquanto debate público, não deixa de causar espanto a violência discursiva que eflui dos comentários de quem não têm os mesmos interesses, a bordejar nas redes sociais e em cenas de controvérsia de opinião quando se insinua $o$ tema das terras indígenas.

É para o gesto de agressividade encenado nessa celeuma que aqui me volto. Para abordá-lo, consequentemente é preciso conjugar interpretações que se lançam em patamares distintos, mas concêntricos, de dilemas colocados na contemporaneidade. Assim, seria possível uma leitura da pressão sobre direitos indígenas englobadas por um círculo maior, o da etapa avançada do capitalismo, que não seja a partir dos marcos jurídicos dos estados-nação frente a populações indígenas, que são, afinal, distintos, mas que seja, pelo menos, pela espantosa semelhança das intempéries que assolam as condições de vida de indígenas nas nações que se fundaram na conquista de seus territórios. Este círculo desce, então, para encontrar o que limita os marcos de convivência étnico e racial nos estados-nação fundados na colonização, até o terceiro, de cada estado-nação assim fundado.

O estado-nação advindo da exploração colonial, o "estado crioulo"3, conforme Benedict Anderson (2008), é analiticamente entendido como de um tipo específico, intrinsecamente vinculado às populações conquistadas e escravizadas. Muito se sabe sobre a construção da identidade dessas nações com base nessa vinculação e o tipo de imaginação nacional que subscrevem - e das práticas de governança que se dirigiram às parcelas daqueles que as constituem, mas que são relegados à condição de minoria e, portanto, de problema. Mas pouco se diz sobre a necessidade da constituição dessas margens de governança como meio mesmo de autodefinição permanente desse tipo de estado e da perpetuação de seu próprio regime de existência. Ademais, a integridade do estado-nação moderno e sua comunidade, qualquer um, se define por suas margens. Há neles como que a

\footnotetext{
${ }^{3}$ Em inglês há o designativo de settler colonies. É sintomático que não tenhamos um sucedâneo na literatura especializada nacional brasileira.
} 
necessidade dessa permanente tensão, há sempre um resquício do atrasado e do negado, cujo índice são as demandas dessas populações, que não cessam no curso da história e continuam sem desenlace. Essa lógica de governança não se restringe às populações à margem, ninguém deixa de ser por ela absorvido, pois trata-se de um sempre renovado horizonte de sentido para a nação (SEGATO, 2002). É uma máquina de poder que não para. Essa máquina talvez responda por que os indígenas - a despeito do genocídio e do etnocídio - não foram totalmente eliminados. É como se esses estados-nação não sobrevivessem sem as margens que criam - de população e de manobra - ou, pelo menos, não conseguissem superar este patamar de violação. Tanto que a contenção - histórica e violenta - dos povos indígenas permanece ideologicamente como fator da soberania em discursos políticos no estado atual.

Tal é o eixo pelo qual circula a dinâmica das autocracias ou das democracias no estado-nação brasileiro. Daí porque as terras e os recursos naturais existentes nas terras indígenas podem permanecer sempre em suspenso legal. Daí também a instabilidade do reconhecimento de quem é indígena e a insistência em distinguir práticas indígenas do presente e do passado - sem se inquietar minimamente diante da extraordinária contradição em admitir a disjunção temporal com eles ainda que estejamos em um único e mesmo tempo presente (FABIAN, 2013). Daí a insistente acusação de que a historicidade dos indígenas, conforme por eles vivida, é mitológica e não "objetiva". Se essa é uma necessidade constitutiva, seria ela permanente do estado-nação formado na colonização? Se assim o for, um sucedâneo para o designativo "estado crioulo" seria "estado-nação ainda colonial" - como o qualificam os movimentos indígenas na América Latina. Esse dar e tomar na tensão constitutiva e permanente dos "estado-nação ainda coloniais", a prevalência constante de "crises", ou este propulsionador da ansiedade social, trazem à mente a prevalência do duplo-vínculo (BATESON, 1980), não à toa observado um sem número de vezes nas mais pequenas e íntimas relações étnicas e raciais nas sociedades coloniais e delas decorrentes: as partes em relação não podem se desvincular e a emissão de significados de quem 
controla o jogo não é linear, direta, ou literal, mas eivada de contradições, a um só tempo de afirmação e de negação do outro.

A tensão no "estado-nação ainda colonial" é reeditada nos recentes ataques aos direitos indígenas. Para examiná-los, volto aos círculos concêntricos acima aludidos para enfocar, a partir deles, a situação no Brasil em três dimensões de discurso e as técnicas de governança que articulam. Uma delas, a dos discursos econômicos, é a que guarda a relação com o círculo abrangente do capitalismo avançado, assim como a segunda, a jurídica, é tangida pelo ideário das políticas culturais neoliberais. Nenhuma das duas, obviamente, são inteiramente inteligíveis, contudo, sem o recurso à configuração específica do estado-nação que aqui se formou e seus marcos próprios de construção de alteridades (SEGATO, 2002). Uma outra dimensão, que entendo que encompassa as duas antes referidas, poderia ser qualificada como "mitológica", desde que se a entenda no sentido estruturalista de expressão imaginária, que se apreende não propriamente na interpretação do sentido do conteúdo de uma narrativa, mas nos elementos que se repetem no conjunto de narrativas de mesmo tipo, e que dizem algumas "verdades" sobre relações sociais e históricas - e desde que se entenda "verdade" e "mito" em conjunção. Faço alusão a mito enquanto linguagem de legado social e cultural, onde se observam estruturas que se repetem e que dão uma organização ao imaginário. E, sobretudo, como linguagem do interdito e do desejo. Verdade e ficção sempre ligadas, a verdade como ficção:

Essa ficção [do mito] mantém uma relação regular com alguma coisa que está sempre implicada por trás dela, e da qual ela porta, realmente, a mensagem formalmente indicada, a saber, a verdade. Aí está uma coisa que não pode ser separada do mito... A verdade tem uma estrutura, se podemos dizer, de ficção (LACAN, 1995, p. 258-259).

Não é sem interesse que, de toda produção intelectual da Europa no século XIX, no momento de ímpetos acalorados de formação da imaginação nacional, tenham sido o evolucionismo social e as teorias raciais as que mais seduziram as elites políticas e letradas brasileiras. Ambas se conectam, realimentam e informam o imaginário a que aludo. 
Como se verá, encontro o espectro desse imaginário na tematização, através dos tempos, da aliança de casamento possível com os índios, seja explicitada ou subjacente em ordenamentos jurídicos no passado, seja alegorizada na literatura romântica e em sua replicação na cinematografia de ficção sobre os índios no Brasil. Atenta que estou ao "caso de amor", é natural que o romantismo literário dê a primeira pista, mas não para estacionar em uma época passada. Tomo o imaginário enquanto uma operação que garante alguma estabilidade - ou a estabilidade possível e a instabilidade sempre aberta - entre a coisa que se imagina, ou da qual se forma a imagem, e o significado dado à tal coisa, sempre passível de deslizamento, de transbordamento, sempre um pouco imaginário, mesmo que tomado como real. E que, portanto, lança luz sobre os deslizamentos entre o direito reconhecido aos índios e os óbices através do tempo na sua efetivação.

\section{A dimensão imaginária: não se pode casar com uma nação inteira}

Marisol de la Cadena (2010) argumenta, na linha da presunção da proximidade dos indígenas à natureza, que esta primeiramente lhes teria conferido a qualificação como improdutivos e, então, sua terra deveria ser incorporada à civilização por meio do trabalho do homem branco. Depois, na modernidade europeia, quando a razão passou a prevalecer sobre a fé, a interação com as coisas da natureza por meios não representacionais - que, obviamente, são ignoradas pela ciência e pela política moderna - foi considerada ausência de razão. Na linha de Latour, a autora sustenta que a antítese entre "humanidade" e "natureza" contaria desde então no campo político, tal como a hierarquia que sela entre humanos superiores e inferiores. Em consequência, todos os mundos onde existem relações com seres-outros-que-humanos, que qualificam as relações indígenas com aquilo que chamamos de "natureza" estariam condenados à extinção (DE LA CADENA, 2010, p. 344-345).

Ainda que a presunção da proximidade entre índio e natureza tenha sido e seja validada nos esquemas mentais do brasileiro, priorizo outro caminho, o da aliança de casamento, para perscrutar o índio no 
imaginário, e não encontro lugar melhor onde ele aflora senão em obras de ficção sobre os índios. Dois romances do século XIX, amplamente conhecidos, Iracema e $O$ Guarani, oferecem a chave dos mitemas que se repetem em produções literárias, televisivas e cinematográficas brasileiras desde então ${ }^{4}$. Não há novidade na referência a essa literatura, a não ser que não pretendo, já que desnecessário por bem conhecida, oferecer novas recensões da mesma. Dos motivos nelas encontrados extraio apenas elementos ou sequências repetidas em todas as obras literárias, televisivas e cinematográficas de ficção sobre os índios abaixo comentadas. $O$ fato de que esse imaginário tenha origem na cultura letrada e tenha sido, assim, conduzido por um pensamento de elite não elide a extensão que alcança. O motivo central que identifico é o da existência de um "caso de amor" entre indivíduos branco e índio (não importando se homem branco e mulher índia ou vice-versa). Pode-se alegar que histórias de amor são populares por assim o serem. Ou pode-se, a partir delas, se elucubrar uma ponte com o tema da aliança como, senão básico, pelo menos interessante às culturas humanas.

Como é de amplo conhecimento, romances novecentistas foram eficazes em apontar a originalidade da nação em sua raiz indígena, em uma imagem de pureza e idílica sequestrada de suas bases reais ${ }^{5}$. Interessa notar que os dois grandes romances desta cepa, acima mencionados, além de suas múltiplas edições ao longo do tempo e vida nas escolas no Brasil, tenham, $O$ Guarani nove vezes e Iracema duas vezes, sido também adaptados para o cinema ${ }^{6}$. Já fora do romantismo, a trilogia de $O$ tempo e o vento, considerada uma das obras literárias mais populares do século XX - e que também enfoca um "caso de amor" entre um índio e uma branca, protagonista da história -, teve o seu volume $O$ continente, primeiramente publicado em 1949, adaptado em partes para o cinema e a televisão: em 1985, em série da TV Globo, que recebeu o

\footnotetext{
${ }^{4}$ A missão que o romantismo literário assume para si na "construção da nação" é bastante conhecida. No século XIX, foi estreita no Brasil a relação entre política e criação literária (ver SCHWARCZ, 1998, para uma abordagem antropológica do diálogo entre literatura e política no século XIX).

${ }^{5}$ Para a construção nacional do índio e do indigenismo ver Ramos, 1997.

${ }^{6}$ Versões de $O$ Guarani: 1903 - Benjamin de Oliveira; 1911 - Salvatore Lázzaro; 1916 - Vittorio Capellaro; 1920 - João de Deus; 1926 - Vittorio Capellaro (produção da Paramount Pictures); 1941 Humberto Mauro (curta metragem educativo O Guarani ato $3^{o}$ - Invocação dos Aimorés); 1950 Riccardo Freda; 1979 - Fauzi Mansur; 1996 - Norma Bengell. Versões de Iracema: 1919 - Vittorio Capellaro; 1979 - Carlos Coimbra.
} 
nome da trilogia, além de para novela televisiva em 1967, e para o cinema em 2013. Cabe, ainda, ressaltar que obras de ficção sobre os índios, ou que os tenham em primeiro foco, sobretudo no cinema, são mais raras, embora abundem filmes etnográficos, filmes de autocrítica à nação, documentários e, mais recentemente, filmes de autoria indígena. Ainda que a produção de ficção seja exígua, no cinema brasileiro o motivo do "caso de amor" entre um índio ou uma índia e uma mulher branca ou um homem branco parece obrigatória e reaparece nos filmes Índia, a Filha do Sol (1982), Brava Gente Brasileira (2000), Terra Vermelha (2008) e Xingu (1912), este último sobre a saga dos irmãos Villas Bôas. Mesmo que com intenção invertida, como no caso de Brava Gente Brasileira, onde se coloca em questão a missão civilizatória; ou crítica da exploração sexual dos índios, como em Terra Vermelha; ou no caso do filme $X i n g u$, que encena fato real desse tipo de encontro amoroso, mostram ainda as marcas do imaginário a que aludo. Não é sem interesse que no recente filme $X i n g u$, que narra a trajetória dos irmãos Villas Bôas, as duas índias são representadas como sendo elas que seduzem os dois irmãos, ou seja, que se demonstrem primeiramente atraídas ou disponíveis. Ademais, a disponibilidade das índias está no imaginário social, detalhado em minúcia em Casa Grande e Senzala e replicado na prostituição de jovens indígenas.

Da parte que cabe à literatura brasileira em formação, Antonio Candido já assinalou que o indianismo estava entre os seus sentimentos dominantes, assim como o nacionalismo e o cristianismo (CANDIDO, 1971 , p. 322). No esforço de independização dessa literatura, ela "recebe suas características do meio, das raças e dos costumes próprios do país"; e "os índios são os brasileiros mais lídimos, devendo-se investigar as suas características poéticas e tomá-las como tema; além do índio, são critérios de identificação nacional a descrição da natureza e dos costumes" (CANDIDO, 1971, p. 329-30). Para além da pureza do índio, reivindicada como ancestralidade da nação e da descrição da exuberância tropical, identifico nessas obras as sequências seguintes, que atravessam as fases da literatura e a cinematografia de ficção: 1) um indivíduo indígena, homem ou mulher, não importa, é acometido de intensa paixão por um homem ou mulher branco/a - nas produções cinematográficas mais recentes, que já incorporam a autocrítica colonial 
e nacional, como Brava Gente Brasileira7 e Terra Vermelha, embora esta atração deslize no sentido dessa crítica, o caso de amor não deixa, todavia, de comparecer; 2) por trás desse indivíduo indígena há a sua comunidade de origem, de quem se isola parcialmente para a realização do caso amoroso, como se não fosse possível tematizar o caso de amor sem que este indivíduo indígena esteja fora de sua comunidade; 3) o caso de amor não elude a guerra entre brancos e índios; ao contrário, ele a supõe, pois a conquista da terra e dos sujeitos indígenas lhe é subliminar; 4) o indivíduo indígena, seja ele/ela representado/a como desejoso do branqueamento ou não, nunca abandona a sua raiz, o que se expressa tanto nas suas atitudes quanto nas de seu/sua parceiro/a frente aos/às mesmos/as; 5) o magnetismo do branco e do mundo do branco é sempre suposto, mas não suficiente para a rendição total.

O que essas sequências informam é que o índio, enquanto um indivíduo, pode comparecer heroicamente para dar valor ao romance e à imaginação da nação. Mas ainda permanece o espectro selvagem, estranho e ameaçador, na figuração da sua comunidade ao fundo. Mesmo que o indivíduo representado na ficção deseje branquear-se e vele pelos elementos simbólicos da missão civilizadora, ele é sempre um só. Não há uma aliança entre nações que se forme deste casamento. Não se casa com uma nação inteira. Um casamento e a ameaça devem ser juntamente preservados. Supõe-se o poder de atração do mundo do branco e, todavia, também a vacilação do/a índio/a ao branqueamento: o mito sabe que este não pode ser total. Pode-se dizer que a sequência mítica não oculta o desiderato do "outro", embora o suponha e queira controlá-lo: nem todos os índios querem/amam os brancos e o mundo dos brancos. O caso de amor entre dois indivíduos é a face assimilacionista nesta economia de desejo, condição irrealizável de que não haja mais índios e, ao mesmo tempo, não haja aliança e reciprocidade - nem terras indígenas.

O dilema do casamento com o/a índio/a no período republicano tutelar é incisivamente ilustrado por fatos reais, que reproduzem elementos da sequência mítica. Um deles é o casamento do sertanista

\footnotetext{
${ }^{7}$ Em outro artigo (PECHINCHA, 2014) argumentei que, apesar dessa intenção crítica, o filme fala mais do "verossímil" para nós do que de uma história própria dos Kadiwéu, ao contrário da expectativa desses últimos que, entretanto, colaboraram com a produção e nele atuaram representando-se a si mesmos no passado.
} 
Ayres da Cunha com a índia Diacuí. Para os mais jovens, que não a conhecem, transcrevo em nota ${ }^{8}$ parte de matéria do jornalista e escritor Mário de Moraes, publicada em $1^{\circ}$ de junho de 2009. O faço tanto pela retomada,, em 2009,, do assunto, como também porque o fato reproduz o final de Iracema (Diacuí se casa com o sertanista e morre ao parir sua filha). Mas o faço, principalmente, pela extraordinária reação de encantamento que se pode observar nos 53 comentários de leitores/as que seguem a matéria, publicada em jornal virtual. Em tempos de grande agressão aos indígenas nas redes sociais não deixa de causar surpresa tamanha manifestação de fascinação com um caso de amor entre um branco e uma índia. A matéria não deixa de informar as "dificuldades burocráticas" da época quanto à possibilidade do casamento de uma "selvagem" com um civilizado.

Em contraponto, o "caso de amor" de dois dos irmãos Villas Bôas com índias, um dos quais é analisado por Rafael Menezes Bastos, no contexto da engenharia de casamentos arranjada pelos Villas Bôas entre grupos indígenas inimigos para promover a pax xinguana (1989) e no das relações de gênero e poder entre brancos e índios (2006). Retoricamente, os irmãos não permitiam o relacionamento sexual das equipes de brancos com as índias, mas se o fazia a despeito dessas regras - que vinham de fora, não foram os índios que primeiramente estabeleceram a sua impossibilidade. Não estou falando, nunca, da razão indígena, para quem a aliança de casamento e o parentesco, o que o faz e seus limites, são distintos dos nossos.

A despeito da possibilidade de miscigenação no Brasil, as narrativas históricas, bem como as estórias populares, que contam sobre o uso dos corpos das índias como produtores de mestiços bastardos, referendam a noção da impossibilidade da legitimidade

\footnotetext{
8“Hoje só os bem idosos irão se lembrar da índia Diacuí, arrancada da mata pelo amor de um sertanista, para uma breve felicidade, cujo fim prematuro e trágico comoveu a todos. O sertanista chamava-se Ayres da Cunha, homem branco, benquisto na tribo de Diacuí. Fascinado pela beleza da índia, Ayres propôs-lhe que viessem para o Rio de Janeiro, onde se casariam. Consultado, o pai de Diacuí consentiu, resolvendo acompanhar o casal à cidade grande. Houve dificuldades burocráticas, pois a maioria se indagava se era correto a um civilizado desposar uma "selvagem", no regime em que o Código Civil mantém nossos silvícolas. Superados os entraves, graças ao prestígio da então poderosa cadeia de Jornais e Emissoras Associados, de Assis Chateaubriand, que encampou a festa, dela tirando o maior proveito publicitário, realizou-se o casamento, que encheu muitas páginas da imprensa, não só nacional como internacional. Diacuí e Ayres da Cunha voltaram para a tribo dispostos a viver mais tranqüilos. Pelo menos era isso que garantia o sertanista. Foi quando a filha do cacique sentiu que ia ser mãe. Diacuí, infelizmente, não chegou a ver o fruto do seu amor, pois morreu do parto!" (MORAES, 2009, n.p.).
} 
desse casamento. Voltando ao período colonial, encontramos referência explícita nas recomendações ao casamento legal no Diretório do Índios, (1757-1798) nas medidas de número 88 a 91, cuja redação demonstra, certamente, que esse óbice social assombrava os "moradores" (como eram chamados, na época, os colonizadores). Tal se pode inferir de seus mandamentos de extinguir a "odiosíssima distinção" entre moradores e índios, de persuadir contra a noção "de qualidade inferior" dos índios, de desterrar "as prejudicialíssimas imaginações dos Moradores deste Estado, que sempre reputaram por infâmia semelhantes matrimônios", e contra o desprezo do cônjuge por sua "qualidade de Índio", e contra o desprezo "as suas alianças, e [a]o seu parentesco".

No que diz respeito ao estímulo ao casamento entre índios e brancos após a promulgação da Lei de Terras, o governo imperial passa, em primeira mão, a apontar a confusão decorrente da miscigenação como índice de não indianidade:

após um século favorecido o estabelecimento de estranhos juntos ou mesmo dentro das terras das aldeias, o governo usa o duplo critério da existência da população não indígena e de uma aparente assimilação para despojar as aldeias de suas terras. Este segundo critério é, aliás, uma novidade que terá vida longa: não se trata, com efeito, simplesmente de aldeias abandonadas mas também do modo de vida dos índios que lá habitam... É uma primeira versão dos critérios de identidade étnica do século $X X$ (CARNEIRO DA CUNHA, 1992a, p. 145).

No século XX, na política de estado o índio ainda comparece como "a origem da nacionalidade brasileira", de forma que reconhecer suas terras é reconhecer o direito da nação ao território que ocupa, os indígenas são vistos como guardas das fronteiras e elementos de colonização e ocupação do espaço geográfico da nação. É neste período que se introduzem no relacionamento do estado com os índios a questão geopolítica, a da "nacionalização dos silvícolas" e, depois da demarcação do Parque Nacional do Xingu, também um novo modelo de terras indígenas. Já a ideia de transitoriedade dos índios renova a de assimilação e de limites ao ser indígena miscigenado. Todavia, o instituto da tutela coloca, se não um óbice total ao casamento legal entre brancos/as e índios/as, pelo menos a questão da sua 
representação tutelar. De qualquer forma, não é mais o casamento o propulsor da "desindianização", mas a educação e a pedagogia da nacionalização (LIMA, 1992 e 1995). O indigenismo republicano se inicia com a condicionalidade entre amor e assimilacionismo. Os índios não devem ser mortos, antes morrer se preciso for, na condição de que serão transfigurados na comunhão nacional. A pacificação revela que a guerra continua (até à rendição). Está aí uma chave para os dilemas do indigenismo do estado: protegidos, mas conquistados e espoliados, tutelados, mas inflexíveis. Com a queda do integracionismo não se pode mais alimentar a fantasia de que o índio venha a devotar total lealdade ao branqueamento.

Em estudos antropológicos da legislação e do indigenismo no Brasil nos períodos colonial e imperial observa-se a preexistência de técnicas de governança que remontam à cada época passada. Em síntese, o que permanece sempre é: 1) a questão da "civilização" ou da "nacionalização" dos índios; 2) da ocupação de suas terras, sempre reconhecidas e tomadas, de forma mais agressiva a partir da segunda metade do XIX; 3) a proteção e a tutela, que já tinha antecedentes coloniais e no Império, estabelecida sobre um status de índio em regime jurídico especial no século XX; 4) permanece sempre também a distinção entre índios "aldeados" e "inimigos", "bravos" ou "mansos" ou "pacificados"; ou, agora, nos discursos dos/as opositores aos direitos indígenas, a distinção entre índios falsos, porque miscigenados ou estrangeiros, ou verdadeiros, porque "genealógicos", técnica disciplinar que comento a seguir.

\section{A segunda dimensão: o que há de comum entre as nações crioulas e settler colonies}

É possível entender a possibilidade ou a interdição de casamentos inter-raciais como técnica de governança, mas que no Brasil o pensamento social empurrou para o terreno do "mito fundador" de uma sociabilidade. Sigo, neste particular da técnica de governança, a proposição da antropóloga Elizabeth Povinelli (2006), que despendeu um longo tempo de pesquisa e convivência entre indígenas australianos. 
Em uma linha de investigação que toma outro rumo que o da identidade e da etnicidade, a autora argumenta que a tanto a interdição a casamentos inter-raciais nas settler colonies quanto o tipo de trabalho e o tipo de administração dos corpos reservado aos étnica e racialmente marcados são compreensíveis à luz da dicotomia que propôs entre sujeitos "autológicos" e sujeitos "genealógicos". Os termos desta dicotomia designam, o primeiro, o indivíduo que, de acordo com o ideário liberal, é autocentrado e diretor de suas escolhas, segundo o mito fundacional do sujeito soberano, origem de toda liberdade, de todo o direito e de toda verdade que esta liberdade reduz. Já o "genealógico", por sua vez, não seria um dado da realidade, onde se incluiriam naturalmente aqueles que se subsumam nos vínculos de ancestralidade e tradicionalidade. "Autologia" e "genealogia" são ambas técnicas de disciplina, capazes de regular como a vida é constituída e distribuída e o mal punido. Assim, o fato de um indígena australiano contar com uma longevidade em muito mais curta que a de seus vizinhos australianos autológicos não pode ser relegado axiomaticamente a razões de sua coletividade. Como no Brasil, onde a longevidade indígena é baixa e as taxas de mortalidade infantil são maiores que o dobro dos demais brasileiros, poder-se-ia aplicar o mesmo esquema explicativo. Mas o que retenho das instigantes ideias da autora, não resumidas aqui como mereceriam, é: primeiro, a ideia de disciplina na administração dos corpos etnicamente marcados para além da limitação da miscigenação racial e, principalmente, as manobras que recobram a construção da "genealogia" no mundo atual. Como demonstra a autora, a construção e as manobras com a ideia de "genealogia" estão no rol da "astúcia" do multiculturalismo neoliberal. Assim, as acusações de impureza ou falsidade étnica que marcam o gesto agressivo contra os indígenas no Brasil poderiam se incluir como um caso dessas artimanhas em toda parte na contemporaneidade, sob os ditames da cultura liberal no capitalismo tardio. A ideia de astúcia do reconhecimento étnico e cultural neoliberal aponta para o interesse na efetivação de um multiculturalismo sem riscos para os estados-nação e para a economia.

As políticas de reconhecimento do multiculturalismo neoliberal alcançam o Brasil quando os avanços constitucionais quanto aos direitos 
indígenas são resultado de um percurso próprio ao indigenismo e às reações ao mesmo. $O$ indigenismo de estado no Brasil foi matizado, no primeiro período republicano, por uma visão evolucionista e um pendor fortemente assimilacionista, com interesse precípuo em consolidar as fronteiras territoriais e estabelecer a ocupação do sertão. Setores do exército à frente de um plano nacionalista que conjugava assimilação, proteção e uso das terras. Seguiu-se a organização de um movimento indígena, amparado pelo setor progressista da igreja católica, por antropólogos e por instituições civis de apoio à causa, que desmascarava o estratagema da emancipação indígena por decreto durante o governo militar, mais um reflexo do acoplamento, no Brasil, entre tutela e/ou proteção e direito a terras. As lutas indígenas se construíram por outra trilha que a do multiculturalismo liberal e de ações afirmativas, que entram no país no início da década de 1990. Hoje o que temos são, por um lado, discursos de viés multiculturalistas progressivamente incorporados em ditames jurídicos e, por outro, uma agressividade em arroubos nacionalistas (quem é o dono da terra) que geram ódio étnico e insensibilização à morte, desamparo e criminalização dos indígenas que lutam por terra. A injúria sobre os corpos é sentida como desigual, alguns podem sofrer mais. Há como que uma exceção psíquica na sensibilidade, que torna confortável e define o aceitável e o que é visto como necessário.

Multiculturalismo neoliberal à parte, obviamente se poderia facilmente associar tais níveis de insensibilidade à herança colonial afinal, já foi diferente? -, com a conquista territorial sempre ao fundo, desde os primórdios, no caso indígena. Se a "genealogia", nos termos de Povinelli, não é a "verdade", mas discurso disciplinar, ela está cerceada de incoerências e pode ser acionada a favor ou contra a quem se destina, como na desmoralização e difamação de práticas indígenas, como no caso da proteção das crianças indígenas contra o infanticídio. Por seu turno, os indígenas entendem que é disciplina, tanto que sabem que se não mantiverem "cultura" (com aspas ${ }^{9}$ ), os recursos e reconhecimento do governo não vem.

É a justaposição entre o discurso do genealógico e a possibilidade ou interdição de casamento inter-racial que me leva a sondar o

\footnotetext{
${ }^{9}$ Cf. Carneiro da Cunha (2009).
} 
esquema mitológico que povoa a vida psíquica do brasileiro na relação com os indígenas.

\section{O gesto de agressão: a transcendência do econômico}

O significante "terra", enquanto recurso natural disponível para a exploração econômica infinita, tem concorrentes reais e concretos nas epistemologias e ontologias indígenas. Assim, um sistema que se universaliza não se unifica como predominante entre todos os coletivos humanos. Atualmente, no Brasil, políticos ruralistas e associados 10 pretendem renovar limites socioideológicos do que seria tolerável em termos de ordenação fundiária e uso do meio ambiente pelo estadonação, sob a rubrica dos "interesses da nação". Pretendem renovar, com isso, regimes de clivagens para situar os outros internos. Como a celeuma atual acomete o direito, mais uma vez o regime de clivagens ganha modulações específicas dadas pelo marco normativo e de interdições desta época (SEGATO, 2002).

Na pletora de acusações amplamente audíveis em registro de falas políticas no Congresso e na mídia, o que se ouve é que os indígenas são residuais e disfuncionais ao desenvolvimento; são miseráveis em decorrência dessa disfuncionalidade; não são índios e, portanto, oportunistas competindo por terras. O direito Ihes confere existência diferenciada e lhes reserva a posse de terras, para nelas viverem "segundo seus usos e costumes e tradições". São, todavia, humanos de direitos que ainda não foram incluídos no projeto de felicidade existencial de produção e consumo.

O discurso das/os opositoras/es das/os indígenas tem que combinar o reconhecimento dos índios como sujeitos de direito com a negativa de sua autorrepresentação, no sentido de que as razões que os povos indígenas elencam para explicar a indissociabilidade de seu modo de vida da posse de seu território sejam consideradas sem significado.

\footnotetext{
${ }^{10}$ Faço, nas linhas seguintes, um condensado de afirmações repetidas entre parlamentares e outros políticos da vertente ruralista, anotadas de registros audiovisuais no Congresso, na impressa e em sites na internet nos últimos três anos, que demandaria uma lista demasiado longa de referências. E mesmo porque nenhuma dessas afirmações foi proferida por um único ruralista, elas se repetem até o cansaço nos discursos acompanhados.
} 
Nos discursos se ouve que os índios são pobres, como os outros pobres da nação brasileira, abandonados e sujeitos à degradação; e cabe ao Estado cuidar tanto dos pobres quanto dos ricos. Alegam, na mesma linha dos índios degradados, o uso das terras indígenas por arrendatários, madeireiros, mineradores e traficantes de drogas como justificativa para não se demarcá-las.

Os indígenas aparecem como os "nossos irmãos índios", e em sua retórica dissimulam até mesmo a piedade. O que realçam é a precariedade de suas condições de vida. Se os índios são pobres, não são culpados por sua indigência, mas sim os/as defensores/as e apoiadores/as dos indígenas que, mediadores/as de interesses escusos, os insuflam, mas não os ajudam a entrar numa forma de vida que se ampara na disputa econômica. $O$ ataque aos indígenas é feito atribuindo-lhes o epíteto de invasores de propriedades particulares, unindo ao qualificativo de pobres, suas reivindicações não podem ser admitidas com base nas diferenças culturais. Assim é que atribuem a "invenção" de suas culturas a antropólogos/as e a outros/as defensores/as dos direitos indígenas, a quem chamam de "ideológicos", antipatriotas, articuladores de interesses internacionais, agentes propugnadores da desordem social, incitadores de invasão de terras.

Os que lutam pelo reconhecimento de sua identidade indígena, por sua vez, são considerados não indígenas. Julgam que seria inexistente ou impossível uma autorrepresentação desses alheia ao campo da cultura dominante. A emergência étnica evoca o velho problema da "pureza" cobrada aos colonizados. Hoje, nem se alega a ideia de mestiçagem como ideal, mas os que não são mais índios, em uma repetição da ideia de pureza também em forma culturalista, agora querendo extirpar as deficiências culturais dos indígenas, como o alcoolismo, a falta de higidez e a falta de progresso: ideias sobre a pureza em quadros epistemológicos transformados, mas que repetem e misturam as concepções sempre coloniais. Para a antropóloga Marisol de la Cadena (2006), que observa o caso peruano e que pode se estender para toda a América de colonização espanhola e portuguesa, "estas definições possibilitaram a continuação das taxonomias coloniais moralmente concebidas [e a das] purezas que estas haviam sustentado e [d]as mesclas que haviam tolerado" (DE LA CADENA, 2006, p. 94). 
O foco do discurso da nação, entendida como sustentáculo ideológico da forma ou espécie de pessoas que devem constituí-la, se desloca numa versão do contrato social: a do papel do precípuo do Estado na representação dos interesses da propriedade privada. Quando o discurso da nação aparece é sob o signo da transcendência econômica, materializada no que se poderia chamar de a "riqueza da nação" e no que pode gerar esta riqueza para o povo que a constitui. A égide do discurso é a responsabilidade do Estado em assegurar a propriedade privada, com um vestígio de hobbesianismo - não o Hobbes que diz que a propriedade privada não é um direito da natureza, mas o que lembra que o Estado deve garantir a propriedade na luta do mais forte contra o mais fraco -, no caso, beneficiando o mais forte. $\mathrm{O}$ que ressoa a formulação clássica da propriedade privada como direito natural cujo fim é ser utilizada para a produção e acumulação capitalista. Há nisso uma ideia de natureza humana, da qual os indígenas participariam como inferiores, posto que inábeis em sua propensão. A atual fratura na conformação do outro indígena (ou uma das fraturas, pois os preconceitos se redizem no tempo) estaria na conduta dos indígenas fora da grade de inteligibilidade cultural do homo oeconomicus, onde o cálculo econômico, aplicado a qualquer área, mesmo a não econômica, é balizador de qualquer conduta racional, como também daquelas que por ela é definida como irracional (FOUCAULT, 2008, p.366-368).

Em tempos de vitória do sistema econômico mundial capitalista, de internacionalização de ideias de direitos humanos e de contradiscursos à colonização e à ocidentalização do mundo, quando o tema da normatização internacional dos direitos indígenas, parcela dos direitos humanos, aparece é para reforçar a ideia de fragilização da soberania nacional. Na mesma linha, tentam claramente manipular e conjugar significantes a seu favor, como o significante "desordem". Ao tempo em que se apresentam como porta-vozes dos interesses comuns, é possível listar um conjunto de expressões que usam para confirmálos, e o fazem como uma advertência sobre um terrível conflito social que estariam prevendo, mas do qual se eximem. Expressões tais como: tensão fundiária; a morte de índios que alimenta a tensão existente e acirra os ânimos entre as partes conflitantes; a insegurança jurídica 
causada por invasões indígenas; a degeneração da segurança quando o Estado não assegura o domínio das propriedades; a ação ilegal de grupos indígenas invasores de terras; a grave ameaça ao estado democrático de direito; o alerta aos poderes constituídos da república contra a sua omissão; a convocação aos "setores conscientes" da nação; o direito de domínio das terras por aqueles que nela labutam. Culpam setores do Estado por uma desordem a vir, pretensamente uma desordem sem precedentes, impulsionada por uma presumida indulgência aos indígenas pelo órgão oficial de assistência que, assim, se afastaria dos ideais verdadeiramente republicanos. O uso da ideia de desordem reflete a ideia de gestão da desordem como produtiva para ação do Estado e da segurança como controle a posteriori (AGAMBEN, 2005). É na administração dessas diferenças como desordem que também o Estado acumula a sua força. De fato, são também de acesso público mais eventual pela mídia nacional e regionais registros da omissão e morosidade na regularização de terras indígenas, assassinatos impunes de lideranças, tentativas de assassinato, ameaças de toda ordem, abuso de poder, racismo e discriminação, violência sexual, suicídio, desassistência à saúde, mortalidade na infância, etc. Ao tempo em que o desconhecimento das histórias indígenas e de sua diferença é muito grande, ainda que muito já se tenha escrito a respeito.

Não se podem considerar razões daqueles para quem a organização coletivista da vida é mais importante que os imperativos individualistas com que leem a sua pobreza. Os índios não teriam razão própria, eles têm, sim, problemas graves de saúde, desnutrição, alcoolismo, problemas que não seriam, como querem, decorrentes da posse de terras. Esta última é que estaria ameaçando a verdadeira vida, pretensamente garantida por uma das agriculturas mais competitivas do mundo e pelas ambicionadas e sempre exploráveis riquezas minerais, hídricas e o potencial agrícola do país. Ademais, a crença na vantagem da competitividade, no cálculo custo/benefício e no destino inescapável do desenvolvimento econômico se generalizam de forma que outras perspectivas possam ser acusadas de colocar em risco a ordem pública. Certas decisões judiciárias e legislativas seriam a metonímia dessas crenças e, portanto, perigosamente figuras sem limites. Cabe notar que, em parte, essas crenças se inscrevem no fundamento da constituição do 
Estado brasileiro, mesmo ao lado do seu fim último, que é o interesse público, encontrado no mandamento de diversos artigos constitucionais. De qualquer forma, para os juristas não há contradição entre a propriedade privada e o fim social. Correlata a essa visão jurídica - que também é histórica e comporta uma noção de ser humano -, é a de que o Estado-nação nunca pode comportar uma totalidade inequívoca e a tentativa de totalização se faz intentando cercar o que se considera "fora" e constituí-lo como dentro dos seus limites, com ressalvas ou condicionantes; portanto, mostrando o que a excetua. A alteração jurídica dos procedimentos e decisão sobre a demarcação de terras indígenas viria para dar livre passagem à realização de interesses particulares. Recordo novamente Foucault, que mostra o surgimento do sujeito de interesses, onde o "interesse" se qualifica como "opção individual, irredutível, intransmissível, [...] princípio de uma opção atomística e incondicionalmente referida ao próprio sujeito" (2008, p. 372). O autor distingue o sujeito de direito - o sujeito do contrato -, que renuncia a alguma coisa, e o homo oeconomicus, cujos interesses são totalmente irrenunciáveis. O ruralista estaria no lugar deste sujeito que não renuncia a nada pelo bem comum, sem se esquecer que o Estado, como limitador e regulador dos interesses deste bem, se inscreve com base em uma noção de ser humano ávido por lucro.

A grade do homo oeconomicus se encaixa perfeitamente nesses discursos de acusação aos indígenas. Ela circunscreve o caso em tela no círculo maior do sistema do capitalismo avançado. Mas ela não é suficiente quando se passa ao terceiro círculo, ou dimensão, o lugar do índio no imaginário brasileiro, passando pela segunda, comum aos estados crioulos e às settler colonies.

\section{A dificuldade em ser uma nação plural}

Hoje o discurso dos ruralistas não sanciona qualquer vínculo com a contribuição indígena à nação e reclama pela incerteza da terra ser indígena. Que os motivos das falas de políticos ruralistas e associados acima mencionados sejam transparentes frente aos seus interesses parece evidente. Entretanto, por que eles também são próprios àqueles 
que não são donos dos mesmos interesses e nem serão por eles beneficiados? Faço esta pergunta porque ela supõe não o espraiamento convincente dos motivos ruralistas, mas sim, ao contrário, uma disposição imaginária, ou melhor, em termos lacanianos, um imaginário que os faz razoáveis para uma ampla audiência. O imaginário, nestes termos, não é nem o real, nem o simbólico, ou o que chamamos na antropologia de representações, embora colado nelas: o imaginário está no vão da conciliação definitiva impossível entre significante e significado, ou o que permite, se de permissão se tratasse, manobras discursivas, de forma que em um momento uma coisa pode ser uma coisa e em outro não - o que neste texto estamos apontando como manobras e incoerências discursivas, portanto políticas. Destaco nos discursos agressivos que hoje se acionam para o ataque aos indígenas o de que os coletivos indígenas que trazem a marca da sua hibridação biológica ou cultural são negados enquanto indígenas e, portanto, não teriam direito a terras. Assim o faço porque o motivo da pureza (ou impureza) biológica e cultural assume posição englobante em relação aos demais.

Antes mesmo da tutela republicana, o casamento legal entre branco e índia encontrava entraves simbólicos, e essa presunção de ilegitimidade reverbera na acusação atual dos ruralistas. Se o casamento interétnico pode ser visto como principal vetor dessa impureza, embora a lei não exija pureza, e por causa da lei, se antes era índice de integração, agora é de inautenticidade indígena.

A guerra justa, a redução de terras, o confinamento, as terras reservadas na República e que prosseguiram sendo usadas - como mostram estudos antropológicos e hoje fato de possível amplo domínio público com a divulgação do Relatório Figueiredo ${ }^{11}$. Terras que permanecem atualmente usadas por não índios, como demonstram as denúncias de invasões possessórias, de exploração ilegal de recursos naturais e danos diversos ao patrimônio indígena. Tudo isso são mostras da ambiguidade do lugar do poder sobre os índios.

\footnotetext{
${ }^{11}$ Disponível em: https://drive.google.com/folderview?id=0BwQXewGzjcAyZlItcC1oUkdDVTQ\&usp=sharing\#list. Acesso em: 15 set. 2015.
} 
Ontem a presença do índio como indicadora da ancestralidade nacional, hoje ambiguidade do poder assegurado na separação e na pureza racial? Não se casa com uma nação inteira, razão pela qual hoje os miscigenados não seriam índios, pois não se prevê mais o índio mestiço ou "aculturado", que trazia a marca da mescla percebida como completada, que o direito não mais admite. O significante, nesta relação, que assegura a posição do poder, a posição do sujeito, é a terra. No limite, se o índio é confinado em um território não disputado, ainda pode permanecer como reserva de abastecimento mítico. A posição fálica e a ameaça de sua perda subjazem na ambiguidade do reconhecimento do indigenato, em estar às voltas com seu designativo moral. Como no que há de sub-reptício nas assertivas tão declaradas de que "não se pode devolver aos índios todas as terras", ou "não se pode devolver aos índios a cidade", ou "toda propriedade privada estará assim ameaçada". Manobras da ambiguidade que comparece também na indagação dos benefícios que o índio e sua cultura poderiam oferecer como se os sujeitos indígenas só pudessem ser reconhecidos como tal se trouxessem algum benefício, como, por exemplo, preservar a natureza - com sentido de dúvida ou mesmo de defesa.

Se no imaginário mítico o indivíduo indígena que se apaixona não confirma o desejo pelo seu grupo, todavia não desmente a sua possibilidade. Enquanto se está sob o controle da política integracionista e da espoliação de suas terras, não há ameaça ao mito pois o indivíduo indígena é o bom selvagem, não está mais em guerra e a terra poderá ser, ao fim, definitivamente liberada. Enquanto a face assimilacionista do estado se manteve, o amor e o ódio puderam ser administrados, quando foi suspensa, restou o ódio. Enquanto se manteve o assimilacionismo, se afastou o fantasma da presença híbrida, que, se retorna, é porque antes o hibridismo era um sossego, pois terminava por retirar o direito à terra, hoje não. A proteção aos indígenas - sempre necessária no estado-nação ainda colonial - pode ser também entendida como uma forma de reter esse fantasma.

A insensibilidade à razão e ao sofrimento indígena que se encontra no país hoje na fala de políticos e seus apoiadores - mais conscientes ou não - revela uma estrutura perversa, transposta ao social (ROUDINESCO, 2008). Essa insensibilidade expressa um imaginário 
social ainda preso à fantasia de que a relação com os índios é (só pode ser) "totalitária". Transformar o indígena em objeto "não ser" foi uma constante aspiração na ação indigenista do Estado, colonial ou não. Ontem e hoje o que se percebe é que não há disposição para nenhuma renúncia, ou seja, é sempre a recusa de que haja sujeito onde só deveria haver objeto-escravo. Não é inócuo que Peri seja um escravo ("por amor") de Ceci, que tanto Iracema quanto a heroína karajá em Índia a filha do sol e o índio Pedro em o Tempo e o Vento morram na história; e que a heroína kadiwéu em Brava Gente Brasileira seja espancada e expulsa por seu parceiro branco por ter tomado uma decisão autônoma; que o protagonista guarani, frente à jovem branca que o seduz em Terra Vermelha e as índias em Xingu estejam em posição de objeto. Em nenhuma dessas histórias de amor o casamento se completa, exceto em O Guarani, mas para que assim o fosse, Peri e Ceci têm que partir para um outro mundo, que o romance não deixa claro qual é, um mundo de fantasia.

Daí negar o indígena naquilo que mais profundamente assegura a sua existência até obter sua angústia. Hoje o desejo do branco é de que o índio desminta o seu desejo, o seu "projeto histórico" (SEGATO, 2014), porque o indigenato não está mais sob o controle do assimilacionismo. Hoje quer se exigir que o indígena ocupe o lugar do fracasso, e é assim que se supera qualquer resistência moral. Este lugar do fracasso reverbera a definição da hipossuficiência indígena em tempos onde se deveria superar os fundamentos tutelares, base da inserção dos indígenas na "comunidade política brasileira":

[...] e a literatura especializada tem apontado a relação entre Estado nacional e expansão da cidadania sobretudo no plano de um acesso mais amplo por parte de certas classes e frações de classe aos direitos civis e sociais, e a uma suposta maior participação cívica e política - a forma como foi concebida a inserção dos indígenas na "comunidade política brasileira" apontava em direção muito distinta e oposta: a possibilidade de terem acesso a direitos básicos, como 0 reconhecimento das terras que ocupam, e a uma assistência diferenciada passava por serem definidos por sua hipossuficiência, como já vimos, fazendo-se necessária a presença de uma agência estatal capaz de 
governá-los, para isso, representando-os politicamente (LIMA, 2012, p. 802).

Ademais, a visão da hipossuficiência indígena no período tutelar republicano também traz ecos do passado, como demonstrou Sampaio (2012) ao investigar a natureza da figura jurídica da tutela no período colonial - portanto, uma disposição colonial de longa duração.

\section{À guisa de conclusão}

A grande questão indígena no país é terras. O indigenato supõe uma moralidade, a moralidade daquele que reconhece o direito e que não pode negar o que reconhece sem negar sua moralidade. Criaramse, então, desde a colônia, o instituto da guerra justa e múltiplas outras manobras sucedâneas para despojar os índios de suas terras, e é em meio a manobras que o discurso e a ação disciplinar asseguram a sua reputação pretensamente sem expor a contradição moral.

As dificuldades, incoerências e desafios em efetivarmos uma nação plural no Brasil vêm sendo apontadas por antropólogos, seja em face das práticas arraigadas de tutela e assimilacionismo do indigenismo oficial, que podem abrir "zonas de deslizamento entre 'políticas da diferença' e ação tutelar" (LIMA, 2012); seja diante das polêmicas atuais acerca da "segurança nacional", pretensamente desafiada pela regularização fundiária de terras indígenas, polêmicas que apontam para a urgente necessidade de discussão ampliada sobre o estatuto da diferença no espaço social (CAVALCANTI-SCHIEL, 2009). De minha parte, tentei paralelizar o caso de amor idealizado entre um indivíduo índio/a e branco/a no imaginário nacional à permanência da mentalidade colonial frente aos povos indígenas no Brasil. $O$ que este imaginário mostra é a face narcísica: "eu te amo contanto que você seja como eu, que você me aprecie mais do que a você mesmo/a e que tenha devoção pelo meu mundo. Como você pode se hibridizar e mesmo assim não manter esta devoção?". A ausência da sensibilização ao sofrimento indígena é decorrente da reação narcísica, a reação daquele que sente o outro como seu. Nisso se tangem o círculo maior do homo oeconomicus no liberalismo tardio com o mais interno da disposição 
ainda colonial nacional, a técnica disciplinar "genealógica" e a decisão sobre o "não ser" do outro indígena. A retórica e as manobras de novos marcos de governança dos índios pelos políticos ruralistas e as elites políticas conservadoras são o ressoar de relações não liquidadas no país do passado colonial, que explicam por que não é possível retirar o índio do lugar de vítima.

Mas esse imaginário também indica o desejo do outro indígena por seus "projetos históricos" desvinculados, ainda que exista, igualmente, uma diferença cultural construída por práticas discriminatórias, onde se exerce uma dimensão totêmica, metafórica, das imagens que se constroem do "nós" e dos "outros". Existe um sistema, modulado no tempo, que atribui um sentido ao "índio" com o qual eles têm que lidar e que é o referencial para a sua fala política, e que inscreve limites à sua fala. $E$ há uma metonímia, uma performatividade dessa identidade por eles. Mas é preciso também entender a justificativa que encontram em si mesmos para sua continuidade ou para sua transformação, sempre em confronto com a exigência de "provar" sua existência por laudo, como quer a lei. "While the justice of an indigenous claim always seems to confront the law with a specific face, the law of recognition always demands that this specific face speak its difference within a legislated norm" (POVINELLI, 2011, p. 27). De qualquer forma, a luta política indígena pela terra no Brasil, levada a diante com gestos de ocupação de seus territórios não demarcados, de ocupação de canteiros de obras, de resistência a despejos, com tenacidade e perseverança indiscutível e sem se eximirem dos riscos que acarretam, são gestos amparados pelo direito.

Não quero simplificar a complexidade da realidade com a ideia, também muito ouvida nos dias de hoje, de que o Estado tem que mediar diversos interesses, embora o tenha. Quando se coloca a transcendência do econômico como mero resultado da história, que, na visão liberal, teria chegado ao seu fim, colocam-se as razões indígenas também nessa história para se dizer que os povos indígenas já não são os mesmos do passado (embora eles sejam os "excluídos da modernidade"). O reconhecimento dos direitos indígenas já se fez por limitação e pretende-se colocar limites ao limite, "des-incluí-lo" por lei. Um embate pelas terras tratadas como exorbitância, um excesso dentro 
da nação. À conquista do direito pelos povos indígenas, querem pospor nova lei, um novo limite, um asilo para o excesso, que pode mesmo ser à beira de uma estrada.

O que se pretende é um "amansamento" da diferença indígena alegando que há uma falha na sua perspectiva - cuja superação exigiria verdadeiramente um giro ontológico. Os indígenas veem um mundo mais estendido, onde todos os seres estão implicados, daí a necessidade de preservar o espaço territorial, que para nós é "reserva", "resto", como diz Davi Yanomami (ALBERT, 2002), é um limite do possível por força da lei. Em face da fase mais veloz e instrumentalizada da ação rapinadora e destruidora do capitalismo, aprecio a formulação de De la Cadena (2010) de que embora possamos compartilhar com os indígenas certos sentidos - por exemplo, se como eles não queremos a destruição da natureza -, não podemos perceber as mesmas consequências dessa destruição. A autora frisa como os indígenas na América Latina estão demandando que os seres-outros-que-humanos entrem no campo da política não meramente de forma metafórica. Trata-se de uma cosmoética que faz frente à perspectiva antropocêntrica e seus correlatos de exploração e destruição. A entrada dos seres-outros-que-humanos na política exigiria uma mudança na sensibilidade que abarcasse disposições dissidentes às dualidades ocidentais da natureza e cultura, do sujeito e do objeto e da grade do homo oeconomicus.

No campo jurídico, o que se espera é que seja impensável a subtração de direitos tão tardiamente adquiridos, e que, ao contrário, se avançasse em direção a uma justiça e uma lei ainda não representadas ou ainda não representáveis (DERRIDA, 2003), que mais efetivamente lograssem ter em pauta a abolição da colonialidade na sua codificação, com as suas implicações epistemológicas e ontológicas. Não que tudo isso sejam utopias, os mitos do colonizador é que as fazem parecer assim.

\section{Referências bibliográficas}


AGAMBEN, Giorgio. A política da profanação. Entrevista concedida a Vladimir Safatle. Folha de São Paulo, Caderno Mais!, 18 set. 2005.

2010 .

Homo Sacer: o poder soberano e a vida nua I. Belo Horizonte: Editora UFMG,

ALBERT, Bruce. O ouro canibal e a queda do céu: uma crítica xamânica da economia política da natureza (Yanomami). In: ALBERT, B.; RAMOS, A. (Org.). Pacificando o branco: cosmologias do contato no noroeste amazônico. São Paulo: Editora da UNESP/Imprensa Oficial do Estado, 2002. p. 239-270.

ANDERSON, Benedict. Comunidades imaginadas. São Paulo: Cia das Letras, 2008.

BATESON, Gregory. Steps to an Ecology of Mind. Nova York: Ballantine Books, 1980.

CANDIDO, Antonio. A formação da literatura brasileira: momentos decisivos. São Paulo: Martins, 1971.

CAPIBERIBE, Artionka; BONILLA, Oiara. A ocupação do Congresso: contra o quê lutam os índios? Estudos avançados, São Paulo, v. 29, n. 83, p. 293-313, 2015.

CARNEIRO DA CUNHA, Manuela. Política indigenista no século XIX. In:

(Org.). História dos índios no Brasil. São Paulo: Cia. das Letras/Secretaria Municipal de Cultura/Fapesp, 1992a. p. 133-54.

Legislação Indigenista no Século XIX: uma compilação - 1808-1889. São Paulo: EDUSP/Comissão Pró-Índio de São Paulo, 1992b.

Cultura com aspas e outros ensaios. São Paulo,:Cosac \& Naify, 2009.

CAVALCANTI-SCHIEL, Ricardo. A política indigenista, para além dos mitos da Segurança Nacional. Estudos Avançados, São Paulo, v. 23, n. 65, p. 149-164, 2009.

DALLARI, Dalmo de Abreu. Reconhecimento e proteção dos direitos dos índios. Revista de Informação Legislativa, Brasília, v. 28, n. 111, p. 315-320, 1991. Disponível em: http://www2.senado.leg.br/bdsf/item/id/175909. Acesso em: 13 set. 2015.

DE LA CADENA, Marisol. ¿Son los mestizos híbridos?: Las políticas conceptuales de las identidades andinas. Universitas Humanistica, Bogotá, v. 61, p. 51-84, 2006.

Indigenous Cosmopolitics: conceptual reflections beyond "Politics". Cultural Anthropology, Chicago, v. 25, n. 2, p. 334-370, 2010.

DERRIDA, Jacques. Força de lei. Porto: Campo das Letras, 2003. 
FABIAN, Johannes. O Tempo e o Outro: como a antropologia estabelece seu objeto. Petrópolis: Vozes, 2013.

FOUCAULT, Michel. O nascimento da biopolítica. São Paulo: Martins Fontes, 2008.

LACAN, Jacques. Seminário 4: A relação de objeto. Rio de Janeiro: Jorge Zahar, 1995.

LÉVI-STRAUSS, Claude. Antropologia Estrutural. Rio de Janeiro: Edições Tempo Brasileiro, 1985.

LIMA, Antonio Carlos de Souza. O governo dos índios sob a gestão do SPI. In: CARNEIRO DA CUNHA, Manuela (Org.). História dos índios no Brasil. São Paulo: Cia. das Letras/Secretaria Municipal de Cultura/Fapesp, 1992. p. 155-171.

Um Grande Cerco de Paz: poder tutelar, indianidade e formação do Estado no Brasil. Petrópolis: Vozes, 1995.

O exercício da tutela sobre os povos indígenas: considerações para o entendimento das políticas indigenistas no Brasil contemporâneo. Revista de Antropologia, São Paulo, v. 55, n. 2, p.781-832, 2012.

MENEZES BASTOS, Rafael José de. Exegeses yawalapití e kamayurá da criação do Parque Indígena do Xingu e a invenção da saga dos irmãos Villas Boas. Revista de Antropologia, São Paulo, v. 30/31/32, p. 391-426, 1989.

Leonardo, a flauta: uns sentimentos selvagens. Revista de. Antropologia, São Paulo, v. 49, n. 2, p. 557-579, 2006.

MORAES, Mário de. A índia Diacuí. Agência Rio de Notícias, $1^{\text {o }}$ jun. 2009. Disponível em http://www.agenciario.com/colunistas.asp?cod_col=11\&pNota=1947\#.VfQuZJeYH3A.

Acesso em: 12 set. 2015.

PECHINCHA, Mônica T. S. A imagem ruim dos Kadiwéu no filme que os defende: uma interrogação sobre o "outro" verossímel no cinema crítico atual. Texto apresentado no I Congreso Cultura en América Latina: Prácticas, significados, cartografias y discusiones "Em memoria de Stuart Hall”. Aguascalientes, Mexico, outubro 2014.

PERRONE-MOISÉS, Beatriz. Índios livres e índios escravos: os princípios da legislação indigenista do período colonial (séculos XXVI a XVIII). In: CARNEIRO DA CUNHA, Manuela (Org.). História dos índios no Brasil. São Paulo: Cia. das Letras/Secretaria Municipal de Cultura/Fapesp, 1992. p. 115-132.

Aldeados, aliados, inimigos e escravos: lugares dos índios na legislação portuguesa para o Brasil. In: Portugal-Brasil: Memórias e Imaginários. Lisboa: GTMECDP, 2000. p.147-64. (Actas do Congresso Internacional Portugal-Brasil: Memórias e Imaginários, 1). 
POVINELLI, Elizabeth. The empire of love: toward a theory of intimacy, genealogy and carnality. Durham/London: Duke University Press, 2006.

The governance of the prior. Interventions, v. 13, n. 1, p. 13-30, 2011.

RAMOS, Alcida R. From Eden to Limbo: the Construction of Indigenism in Brazil. In: BOND, George; GILliAM, Angela (Org.). The Social Construction of the Past: Representation as Power. Londres: Routledge, 1997. p. 74-88.

ROUDINESCO, Elisabeth. A parte obscura de nós mesmos: uma história dos perversos. Rio de Janeiro: Jorge Zahar, 2008.

SAMPAIO, Patrícia Maria Mello. Fronteras de la libertad: tutela indigena en el Diretorio Pombalino e en la Carta Regia de 1798. Boletin Americanista, v. LXII, n. 64, p. 13-22, 2012.

SEGATO, Rita. Identidades políticas y alteridades históricas: una crítica a las certezas del pluralismo global. Nueva Sociedad, n. 178, p.104-125, 2002.

El sexo y la norma: frente estatal, patriarcado, desposesión, colonidad. Estudos Feministas, Florianópolis, v. 22, n. 2, p. 593-616, 2014.

SCHWARCZ, Lilia M. As barbas do Imperador: D. Pedro II, um monarca nos trópicos. São Paulo: Companhia das Letras, 1998.

Recebido em: 08/02/2016* Aprovado em: 07/05/2016 * Publicado em: 30/06/2016 